\title{
Composition of the outer membrane of Proteus mirabilis in relation to serum sensitivity in progressive stages of cell form defectiveness
}

\author{
Nicola Siegmund-Schultze, ${ }^{1}$ Hein-Peter Kroll, ${ }^{2}$ Hans H. Martin ${ }^{1}$ and \\ KATHRYN NIXDORFF ${ }^{1 *}$ \\ ${ }^{1}$ Institut für Mikrobiologie, Technische Hochschule Darmstadt, Schnittspahnstr. 10, D-6100 Darmstadt, Germany \\ ${ }^{2}$ Bayer AG, Institut für Chemotherapie, Postfach 101709, D-5600 Wuppertal 1, Germany
}

(Received 21 March 1991; revised 17 July 1991; accepted 27 August 1991)

\begin{abstract}
A serum-resistant strain of Proteus mirabilis was used to determine whether changes in the composition of surface components could be detected following induction of progressive stages of cell form defectiveness by $\beta$-lactam antibiotics. The critical stage was the conversion from filaments to the spheroplast form, which was accompanied by increased susceptibility to the bactericidal action of human serum. Inner and outer membranes of the bacterium, its filament form and its spheroplast form were separated by sucrose density-gradient centrifugation after digestion of peptidoglycan, followed by osmotic lysis of the cells. Outer membranes of the bacterial and the filament forms sedimented at the same density, whilst the outer membrane fraction of the spheroplast form sedimented in a region of lesser density. In addition, the amounts of two major outer-membrane proteins as well as the O-polysaccharide content of the lipopolysaccharide were reduced in the spheroplast form. These results indicate a general disorganization in structure and assembly of components in regard to their interactions with one another in the outer membrane of the spheroplast form.
\end{abstract}

\section{Introduction}

Invading bacteria are primarily recognized and attacked by the immune system through cell surface structures, and any changes in surface components could affect immune processes. This is especially relevant for the bactericidal action of serum complement on Gramnegative bacteria, as components of the outer membrane of these micro-organisms can act as a barrier to the killing effects of complement (Taylor, 1983; Goldman et al., 1984). Of particular importance in this regard are the effects of antibiotics on cell surfaces of bacteria.

It has been well established that treatment of Escherichia coli with $\beta$-lactam antibiotics affects biosynthesis of peptidoglycan, leading to functional disorganization and morphological changes. Although peptidoglycan synthesis is the primary target, secondary effects on Gram-negative bacteria could be expected, such as destabilization of the association of peptidoglycan with the outer membrane, which in turn might lead to disorganization of assembly and loss of outer membrane components.

The effects of $\beta$-lactam antibiotics on the composition

Abbreviations: LPS, lipopolysaccharide; PBP, penicillin-binding protein. of the outer membrane of Gram-negative bacteria have not been studied systematically. There are, however, a number of reports documenting changes in outer membrane or surface components after treatment of these bacteria with various $\beta$-lactam antibiotics (James, 1975; Taylor et al., 1982; Nixdorff et al., 1985; Suerbaum et al., 1987). As shown first in E. coli and later in related enterobacteria, progressive stages of defective cell shape and cell wall structure are caused by the action of $\beta$-lactam antibiotics binding preferentially to individual penicillin-binding proteins (PBPs) which perform essential functions in different stages of peptidoglycan synthesis and morphogenesis. Depending on their different binding selectivities, the antibiotics either cause uniform cell wall defects or induce progressive defects at increasing concentrations as the result of successive binding to additional PBP targets (Spratt, 1975, 1977; Curtiss et al., 1979; Ohya et al., 1979; Georgopapadakou, 1988).

For the present studies a model system derived from the serum-resistant strain Proteus mirabilis VI was used. The system includes the bacterial form, its filament form induced by cefuroxime and its spheroplast form induced by cefoxitin. The decisive advantage of working with the $P$. mirabilis system is the ability of these organisms to survive and multiply extensively in all different stages of 
cell wall damage in the presence of $\beta$-lactams, a condition that has been designated the L-form state (Dienes \& Weinberger, 1951). Thus, the requirement for growing cultures in bactericidal assay systems (Taylor, 1983) can be met, and uniform populations of the walldefective states can easily be obtained for biochemical characterization (Martin \& Gmeiner, 1979; Martin, 1983). This is in striking contrast to the transient nature of filament and spheroplast states of $E$. coli and closely related enterobacteria. With these organisms, the inactivation of essential PBPs is lethal, and sufficient uniform cell material for analyses cannot be obtained.

In the present investigation, comparative biochemical analyses were carried out on the outer-membrane fractions of the bacterial, the filament and the spheroplast forms of $P$. mirabilis VI. Also, the susceptibility of all three cell forms to the bactericidal action of human serum was examined.

\section{Methods}

Bacteria. P. mirabilis VI was from the collection of H. H. Martin.

$\beta$-Lactam antibiotics. Cefuroxime was purchased from Hoechst and cefoxitin was purchased from Merck, Sharp \& Dohme.

Cultivation of the bacterial form. An overnight culture of $P$. mirabilis $\mathrm{VI}$ in $50 \mathrm{ml} \mathrm{L}$-medium (Martin, 1964), incubated at $37^{\circ} \mathrm{C}$ with shaking at 120 r.p.m., was added to 1 litre L-medium to an $\mathrm{OD}_{578}$ of 0.3 . The culture was incubated as above to late exponential phase $\left(\mathrm{OD}_{578}=0.8\right)$.

Induction and cultivation of the filament form. P. mirabilis VI was induced to filament formation $1 \mathrm{~d}$ before use in an experiment by addition of $0.1 \mu \mathrm{g}$ cefuroxime ( $\mathrm{ml} \mathrm{L}$-medium $)^{-1}$, and cultivated as described in the bacterial form.

Induction and cultivation of the spheroplast form. P. mirabilis VI was induced to spheroplast formation $2 \mathrm{~d}$ before use by addition of $60 \mu \mathrm{g}$ cefoxitin ( $\mathrm{ml} \mathrm{L}$-medium) ${ }^{-1}$. An overnight culture of the bacteria was inoculated into $\mathrm{L}$-medium and incubated at $37^{\circ} \mathrm{C}$ with increasing degrees of shaking during the day (70 and 90 r.p.m.) and finally at 120 r.p.m. overnight. A second culture was inoculated from this material and incubated overnight at $37^{\circ} \mathrm{C}$ with shaking at 120 r.p.m. This overnight culture was added to 1 litre L-medium to an $\mathrm{OD}_{578}$ of 0.3 and incubated at $37{ }^{\circ} \mathrm{C}$ with shaking at 120 r.p.m. to late exponential phase. The medium always contained $60 \mu \mathrm{g}$ cefoxitin $\mathrm{ml}^{-1}$. Complete spheroplast formation in P. mirabilis VI was also obtained in the same manner by increasing the concentration of cefuroxime from the filament-forming concentration of $0.1 \mu \mathrm{g} \mathrm{ml}^{-1}$ to $10 \mu \mathrm{g} \mathrm{ml}^{-1}$ (Huber, 1985). At these concentrations of antibiotics, growth of the spheroplasts was not inhibited.

Preparation of inner and outer membranes. Isolation of inner and outer membranes on sucrose density gradients was done according to Taylor \& Kroll (1984). Briefly, cells were cultivated to late exponential phase in $\mathrm{L}$-medium; one portion was labelled with $0.33 \mu \mathrm{Ci}\left[2-{ }^{3} \mathrm{H}\right]$ glycerol $\mathrm{ml}^{-1}$ (specific activity, $1 \mathrm{Ci} \mathrm{mmol}{ }^{-1}, 37 \mathrm{GBq} \mathrm{mmol}^{-1}$; Amersham) for incorporation into phospholipids, and another with $0.05 \mu \mathrm{Ci} N$-acetyl$\mathrm{D}-\left[1-{ }^{14} \mathrm{C}\right]$ glucosamine $\mathrm{ml}^{-1}$ (specific activity, $40-50 \mathrm{mCi} \mathrm{mmol}^{-1}$, 1.48-1.85 GBq mmol${ }^{-1}$; Commissariat a l'Energie Atomique, Gif-surYvette, France) for incorporation into lipopolysaccharide (LPS).
Peptidoglycan was digested with lysozyme and the cells were ruptured by osmotic shock. If the osmolysis was not effective, the cells were lysed by shaking with glass beads in a cell mill for 5-10 min. Membrane material was harvested by ultracentrifugation and separated into inner and outer membranes on a linear sucrose density gradient $(15-65 \%$, $w / w)$ by ultracentrifugation. Fractions containing 20 drops were collected from the bottom of the centrifuge tube. Absorbance was monitored at $278 \mathrm{~nm}$; sucrose concentrations were measured by refractometry.

Analytical methods. Protein content was determined by the method of Markwell et al. (1978). Fatty acids of phospholipids and LPS were analysed by gas-liquid chromatography according to Gmeiner \& Martin (1976). SDS-PAGE of proteins in membrane fractions was carried out in a slab gel apparatus (GE4; Pharmacia LKB) according to Lugtenberg $e$ t al. (1975) as previously described (Nixdorff $e t$ al., 1977). Estimation of the O-polysaccharide chain length of LPS was made by amino acid analysis of lysine and $N$-acetyl-D-glucosamine as described by Gmeiner (1975). LPS was extracted from whole cells of the bacterial form and the spheroplast form by the phenol/water method (Westphal et al., 1952).

Bactericidal assay. A modification of the photometric assay of Muschel \& Treffers (1955) was used. Normal human serum in amounts ranging from 0.03 to $2.25 \mathrm{ml}$ was brought to $2.25 \mathrm{ml}$ with L-medium. Corresponding amounts of heat-inactivated serum were included as controls. Thereafter, $0.75 \mathrm{ml}$ of a late exponential phase culture was added and the contents were mixed. At time $0,0.8 \mathrm{ml}$ was removed for measuring $\mathrm{OD}_{578}$. The tubes were incubated at $37^{\circ} \mathrm{C}$ in a shaker water bath for $60 \mathrm{~min}$ (kill period). An aliquot $(0.8 \mathrm{ml})$ was removed and $1.0 \mathrm{ml} \mathrm{L}$-medium was added to each tube. The tubes were incubated for an additional $90 \mathrm{~min}$ (outgrowth of the surviving organisms) and a final $\mathrm{OD}_{578}$ measurement was made. The percentage survival was calculated by dividing the $\mathrm{OD}_{578}$ of tubes containing active human serum by the $\mathrm{OD}_{578}$ of tubes containing the respective concentration of heatinactivated human serum and multiplying by 100 .

Normal human serum. Blood was collected aseptically from healthy volunteers and allowed to clot at room temperature for $1 \mathrm{~h}$ and 3-4 $\mathrm{h}$ thereafter at $4^{\circ} \mathrm{C}$. Clots were removed and the serum was collected by centrifugation and sterilized by filtration. Sera were stored in aliquots of $1.0 \mathrm{ml}$ at $-80^{\circ} \mathrm{C}$ until use. Pooled human serum was also obtained from the German Red Cross (Hagen/Westfalen, Germany).

\section{Results}

\section{Separation of membranes}

Centrifugation of membranes of the bacterial, filament and spheroplast forms of $P$. mirabilis VI on sucrose density gradients produced the profiles presented in Fig. 1. The separation profile of membranes of the bacterial form (Fig. 1a) revealed essentially four fractions with peak densities of $1.27,1.25,1.19$ and $1.16 \mathrm{~g} \mathrm{ml}^{-1}$ (peaks $1-4$, respectively). Incorporation of radioactive marker molecules into the membrane fractions gave a first indication of the location of inner and outer membranes in the gradient. Incorporation of $\mathrm{N}$-acetyl-D-[1-14 C]glucosamine into mainly LPS and peptidoglycan would be expected. It serves as a specific marker of the outer membrane after removal of peptidoglycan by lysozyme 

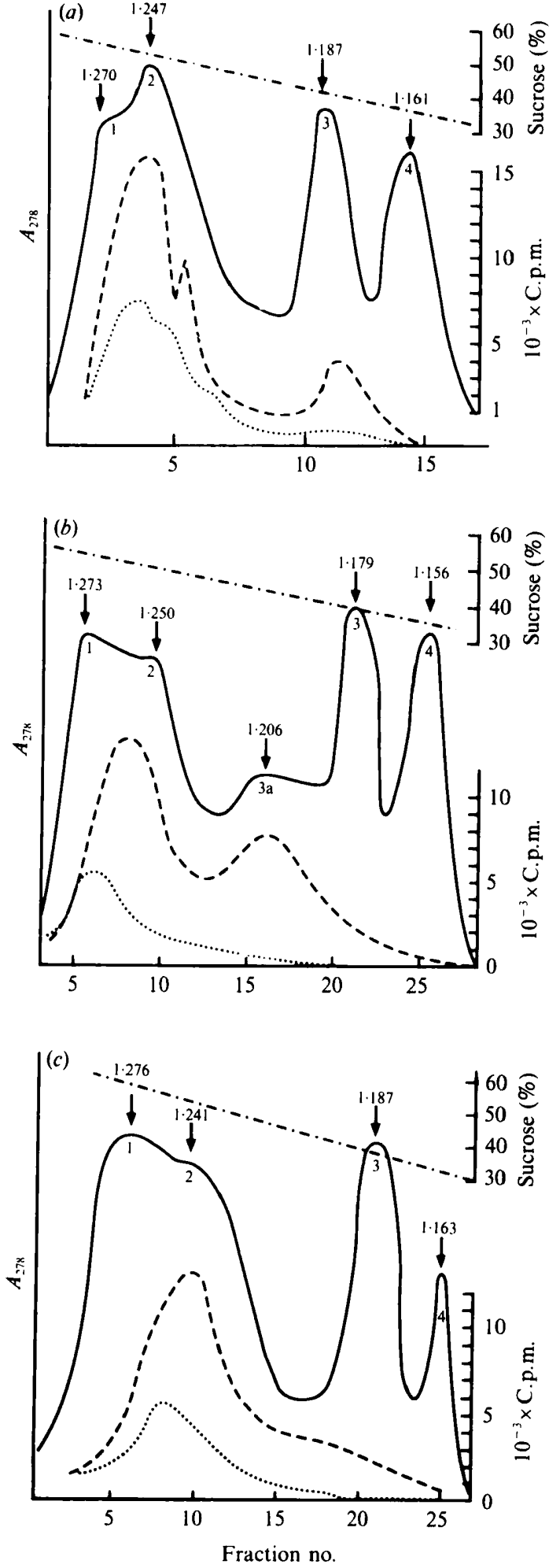

Fig. 1. Separation of membranes from the bacterial (a), filament (b) and spheroplast $(c)$ forms of $P$. mirabilis VI in linear $(15-65 \%, w / w)$ sucrose density gradients. Numbers at positions indicated by arrows are peak densities $\left(\mathrm{g} \mathrm{ml}^{-1}\right) .-\cdots \cdot$, Sucrose concentration;,$-- A_{278}$; incorporation of $\left[2-{ }^{3} \mathrm{H}\right] \mathrm{glycerol}(--)$ and $\mathrm{N}$-acetyl-D-[1-14 $\mathrm{Clglucos}-$ amine $(\cdots \cdot)$ is given as c.p.m. digestion during the membrane separation procedure. Any remaining peptidoglycan fragments would tend to associate with outer membrane material upon separation in sucrose density gradients (Osborn et al., 1972). $\left[2-{ }^{3} \mathrm{H}\right] \mathrm{Glycerol}$ was used as a marker for phospholipids. The greater portion of $N$-acetyl-D-glucosamine incorporated into the membrane fractions of the bacterial form was found in the material contained in the first two peaks. Accumulation of $\left[2-{ }^{3} \mathrm{H}\right]$ glycerol in phospholipids was also greatest in these two fractions. Some $\left[2-{ }^{3} \mathrm{H}\right]-$ glycerol, far less than expected, was incorporated into the material of the third peak, whilst almost none was present in the fourth peak. These results tentatively located outer membrane material in the area of the first two peaks, and cytoplasmic membranes in the third and possibly the fourth peaks. An additional fraction with a peak density of $1.21 \mathrm{~g} \mathrm{ml}^{-1}$ (peak 3a) was seen in the profile of the filament form (Fig. $1 b$ ). It should be noted that the gradient profiles reported in Fig. 1 were highly reproducible in repeated experiments and were characteristic for the different cell forms of $P$. mirabilis VI.

\section{Analyses of proteins in the gradient fractions}

Analyses of the proteins contained in the membrane fractions by SDS-PAGE (Fig. 2) showed very similar patterns for the bacterial and the filament forms, in that the four major outer-membrane proteins of $P$. mirabilis VI detectable by SDS-PAGE were concentrated in peak 1 (membranes with a buoyant density of $1.27 \mathrm{~g} \mathrm{ml}^{-1}$ ). They represent proteins with approximate molecular masses of 39, 36, 19 and $15 \mathrm{kDa}$ (Gmeiner, 1981; Nixdorff et al., 1977). The proteins in peaks 3 and 4 represent other, primarily cytoplasmic membrane proteins, which show distinctly characteristic patterns of mobility in SDS-PAGE (Hasin et al., 1974; Kroll et al., 1980; Van Heerikhuisen et al., 1975).

The protein pattern of the spheroplast form (Fig. 2c) was decidedly different. The major outer-membrane proteins were most prominent in peak 2. Furthermore, there was an apparent reduction in the amounts of the $19 \mathrm{kDa}$ and possibly the $15 \mathrm{kDa}$ outer-membrane proteins. This was also observed previously in cell wall fragments isolated from the spheroplast form (Nixdorff et al., 1985).

The protein patterns represented in Fig. 2 were highly reproducible.

Comparative analyses of LPS and phospholipids in membrane fractions isolated from the bacterial, filament and spheroplast forms of $\boldsymbol{P}$. mirabilis VI

Analyses of the amounts of LPS and phospholipids in the membrane fractions of the various forms (Table 1) 


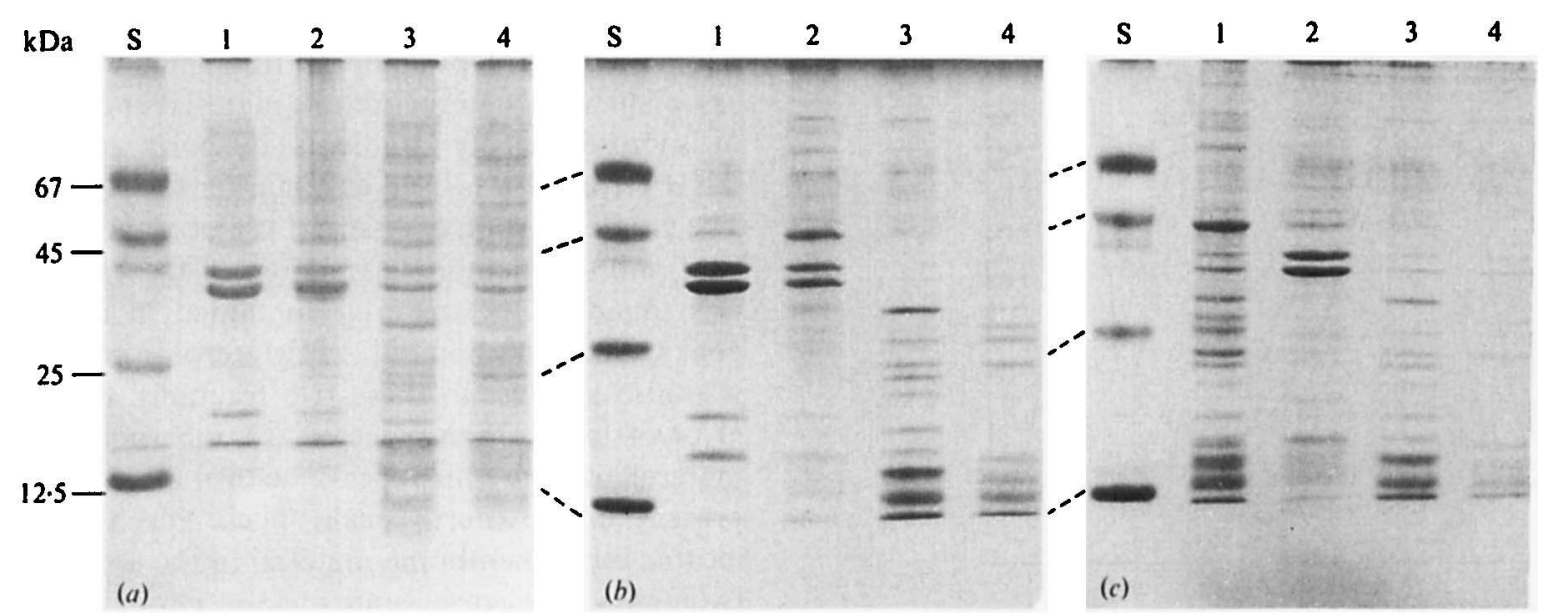

Fig. 2. SDS-PAGE of proteins in the outer and inner membranes of $P$. mirabilis VI bacterial form (a), filament form (b) and spheroplast form $(c)$. Lanes: $S$, standard proteins; $1-4,45 \mu \mathrm{g}$ protein from sucrose density-gradient fractions harvested at peak densities of 1.27 (lane 1), 1.25 (lane 2), 1.19 (lane 3) and 1.16 (lane 4) $\mathrm{g} \mathrm{ml}^{-1}$.

Table 1. Quantitative analyses of amounts of phospholipids and LPS in membrane fractions of the bacterial form, the filament form and the spheroplast form of $P$. mirabilis VI

Values in the table represent the means \pm SE from two determinations each on two to five separate samples.

\begin{tabular}{lcc}
\hline \hline $\begin{array}{c}\text { Gradient } \\
\text { sample }\end{array}$ & $\begin{array}{c}\text { Phospholipids } \\
\text { [nmol 16:0* } \\
\text { (mg protein) }\end{array}$ & $\begin{array}{c}\text { LPS } \\
\text { [nmol 3-OH-14:0† } \\
\text { (mg protein) }\end{array}$ \\
\hline Bacterial form, peak 1 & $411.92 \pm 30 \cdot 1$ & $165 \cdot 75 \pm 9.9$ \\
Filament form, peak 1 & $343.40 \pm 69 \cdot 1$ & $265 \cdot 10 \pm 50.5$ \\
Spheroplast form, peak 1 & $140.83 \pm 46.3$ & $35 \cdot 55 \pm 10.7$ \\
Spheroplast form, peak 2 & $247.76 \pm 49.7$ & $154.71 \pm 32.9$ \\
\hline \hline
\end{tabular}

\footnotetext{
- 16:0= palmitic acid.

† 3-OH-14:0 = 3-hydroxytetradecanoic acid (3-hydroxymyristic acid).
}

confirmed the presumption that outer membranes of the bacterial and the filament forms were located in gradient peak 1 , while the outer membrane of the spheroplast form was located primarily in gradient peak 2. As a measurement of LPS content, the amount of 3-hydroxytetradecanoic acid (3-OH-14:0) in the sample was determined and reported per $\mathrm{mg}$ protein. Phospholipids were measured as total content of hexadecanoic acid (16:0) minus the content of 16:0 in LPS in the sample. LPS and phospholipids were present in peak 1 gradient fractions of both the bacterial and the filament forms in ratios similar to those reported for the outer membrane of E. coli (Nakamura \& Mizushima, 1975). In comparison, the material in peak 1 of the spheroplast membranes contained much less LPS. However, peak 2 of the spheroplast form contained LPS and phospholipids in amounts similar to those found in peak 1 of the other forms.
Analyses of the fatty acid composition of the phospholipids in the outer membrane fractions isolated from the three forms of $P$. mirabilis VI showed no detectable differences (data not shown).

Comparison of the $O$-polysaccharide content of LPS from the bacterial form and the spheroplast form of P. mirabilis VI

It was of particular interest to determine whether any change in the type of LPS could be detected in the spheroplast form of $P$. mirabilis VI, especially because of the changes in outer membrane composition of the spheroplasts reported above.

LPS from $P$. mirabilis VI contains, as strain-specific components, lysine and galactosamine in the O-polysaccharide chain, which can be measured by amino acid analysis (Gmeiner, 1975). Therefore, determination of the amounts of these two components per mole of 3-OH-14:0 (lipid A) gives an estimation of the relative length of the O-polysaccharide chain. In Table 2, the results show that the ratio of lysine to galactosamine in

Table 2. Content of lysine and galactosamine in LPS from the bacterial form and the spheroplast form of $P$. mirabilis $V I$

\begin{tabular}{lcc}
\hline \hline $\begin{array}{c}\text { LPS } \\
\text { source }\end{array}$ & $\begin{array}{c}\text { Galactosamine } \\
\text { [nmol } \\
\left.\left(\mathrm{nmol} 3-\mathrm{OH}-14: 0^{*}\right)^{-1}\right]\end{array}$ & $\begin{array}{c}\text { Lysine } \\
{[\mathrm{nmol}} \\
\left.\left(\mathrm{nmol} 3-\mathrm{OH}-14: 0^{*}\right)^{-1}\right]\end{array}$ \\
\hline Bacterial form & 2.150 & 0.937 \\
Spheroplast form & 1.026 & 0.469 \\
\hline \hline
\end{tabular}

*3-OH-14:0 = 3-hydroxytetradecanoic acid (3-hydroxymyristic acid). 
Table 3. Serum sensitivity of different cell forms of P. mirabilis VI

Percentage survival is reported as means \pm SE of values taken from three to five separate experiments.

\begin{tabular}{|c|c|c|c|c|}
\hline \multirow{2}{*}{$\begin{array}{l}\text { Normal } \\
\text { human } \\
\text { serum } \\
(\%, v / v)\end{array}$} & \multicolumn{4}{|c|}{ Percentage survival } \\
\hline & Bacteria & $\begin{array}{c}\text { Filaments } \\
\left(0.1 \mu \mathrm{g} \text { cefuroxime } \mathrm{ml}^{-1}\right)\end{array}$ & $\begin{array}{c}\text { Spheroplasts } \\
\left(60 \mu \mathrm{g} \text { cefoxitin } \mathrm{ml}^{-1}\right)\end{array}$ & $\begin{array}{c}\text { Spheroplasts } \\
\left(10 \mu \mathrm{g} \text { cefuroxime } \mathrm{ml}^{-1}\right)\end{array}$ \\
\hline $\begin{array}{r}75 \\
60 \\
50 \\
40 \\
25 \\
10 \\
3\end{array}$ & $\begin{array}{r}89.4 \pm 6.3 \\
92 \cdot 2 \pm 4.5 \\
97.2 \pm 2.8 \\
90.8 \pm 6.5 \\
96.8 \pm 3.2 \\
97.5 \pm 2.2 \\
100.0 \pm 0\end{array}$ & $\begin{array}{r}76 \cdot 5 \pm 8 \cdot 6 \\
82.9 \pm 4 \cdot 3 \\
86 \cdot 7 \pm 7 \cdot 6 \\
87 \cdot 2 \pm 2 \cdot 1 \\
98 \cdot 0 \pm 1 \cdot 1 \\
97 \cdot 4 \pm 2 \cdot 6 \\
100.0 \pm 0\end{array}$ & $\begin{array}{r}8 \cdot 9 \pm 2 \cdot 2 \\
13 \cdot 1 \pm 3 \cdot 4 \\
38 \cdot 4 \pm 2 \cdot 6 \\
62 \cdot 9 \pm 3 \cdot 1 \\
88 \cdot 3 \pm 3 \cdot 3 \\
98 \cdot 1 \pm 1 \cdot 3 \\
100 \cdot 0 \pm 0\end{array}$ & $\begin{array}{l}22.9 \pm 0.8 \\
39.8 \pm 2 \cdot 6 \\
58.2 \pm 4 \cdot 2 \\
77.0 \pm 21 \cdot 0 \\
91.5 \pm 12 \cdot 9 \\
94.6 \pm 10 \cdot 1 \\
85.3 \pm 32.4\end{array}$ \\
\hline
\end{tabular}

the LPS of both the bacterial and the spheroplast forms is constant, as would be expected. However, the bacterial form contains twice as much lysine and galactosamine per mole of 3-OH-14:0 as the spheroplast form. Thus, the O-polysaccharide content of the LPS in the spheroplast form is approximately half of that found in the LPS of the bacterial form.

\section{Serum sensitivity of spheroplast forms of P. mirabilis VI}

Conversion to serum sensitivity occurred after induction of $P$. mirabilis VI to the spheroplast form with cefoxitin (Table 3). Similar results were obtained previously in a preliminary investigation (Siegmund-Schultze et al., 1985). P. mirabilis VI was also converted into uniform spheroplasts by applying a concentration of cefuroxime higher than that used to specifically induce filament formation. These spheroplasts were only slightly less sensitive to the effect of complement than the spheroplasts induced by cefoxitin.

\section{Discussion}

The results of these studies show that the outer membrane of the spheroplast form of $P$. mirabilis VI induced by the $\beta$-lactam antibiotic cefoxitin has a composition and character different from the outer membrane of the bacterial form, or of its filament form induced by a low concentration of cefuroxime.

The regulation of the synthesis or translocation of outer membrane components of the spheroplast form may be disturbed in some way (Rogers \& Thurman, 1983). This is particularly indicated by the changes in protein composition and the amount of O-polysaccharide in LPS. It is possible that subtle changes in the qualitative or quantitative composition of outer membrane components could lead to changes in outer membrane density, as observed in the spheroplast form.
Alternatively, a defect in the organization of peptidoglycan might lead to an instability, a reorganization or redistribution of components in regard to their interactions with one another in the outer membrane. This could cause a stronger tendency of components of the inner and outer membranes to associate, particularly during attempts at isolation.

The observed disorganization of the outer membrane of the spheroplast form occurred in parallel with at least a partial loss of serum resistance. Induction to the spheroplast form was therefore a very critical event with regard to alteration of serum sensitivity. This was accentuated with the conversion of the resistant bacterial form to serum-sensitive spheroplasts by two different $\beta$-lactam antibiotics. These results are consistent with the view that various $\beta$-lactams use different lines of attack on a system consisting of multiple targets to initiate a series of events leading to functional disorganization of the cell envelope, expressed as cell form defects in rod-shaped bacteria (Martin, 1983). Rather extensive disorganization of the outer membrane can accompany spheroplast formation, as elaborated by the analyses of the surface components of the cefoxitin-induced spheroplasts discussed above.

The interaction of peptidoglycan with the outer membrane surely contributes to the stability of the cell envelope. Electron micrographs of spheroplasts of $P$. mirabilis show extensive loss of outer membrane fragments in the form of spherical particles which slough off the surface (Hofschneider \& Martin, 1968). Thin sections of penicillin-induced spheroplasts of $E$. coli viewed in the electron microscope show occasional large spaces between inner and outer membranes (Schnaitman, 1970) as well as areas of total detachment of the outer membrane from the cell surface (Gumpert et al., 1971). These exposed areas of cytoplasmic membrane might represent more accessible targets for the binding and activation of complement components. Alternatively, or in addition, peptidoglycan-free areas might 
allow more extensive interaction of inner and outer membranes, which would reduce the distance between them and promote destruction by complement (Bhakdi et al., 1987).

One factor that apparently plays a role in resistance of Gram-negative organisms to the bactericidal action of complement is the amount of O-polysaccharide in LPS (Goldman et al., 1984; Joiner et al., 1984; Reynolds \& Pruul, 1971). Whether the observed reduction in the amount of O-polysaccharide in the outer membrane of the spheroplast form was alone decisive is difficult to assess. Taylor et al. (1981) have reported that treatment of several clinical isolates of $E$. coli with subinhibitory concentrations of mecillinam led to the formation of spherical (round) cells along with increased sensitivity to the bactericidal action of serum. Further studies (Suerbaum et al., 1987) showed that LPS in the outer membrane of these spherical cells had shorter O-polysaccharide chains. Despite differences in bacterial strains and antibiotics employed, there are definite parallels between the results of these studies and those reported here.

This work was supported by the Deutsche Forschungsgemeinschaft. Our special thanks go to Jobst Gmeiner for valuable discussions and for so kindly performing the amino acid analyses.

\section{References}

Bhakdi, S., Kuller, G., Muhly, M., Fromm, S., Seibert, G. \& PARRISIUS, J. (1987). Formation of transmural complement pores in serum-sensitive Escherichia coli. Infection and Immunity 55, 206-210.

Curtiss, N. A. C., OrR, D., Ross, G. W. \& Boulton, M. G. (1979). Competition of $\beta$-lactam antibiotics for the penicillin-binding proteins of Pseudomonas aeruginosa, Enterobacter cloacae, Klebsiella aerogenes, Proteus rettgeri and Escherichia coli: comparison with antibacterial activity and effects upon bacterial morphology. Antimicrobial Agents and Chemotherapy 16, 325-328.

Dienes, L. \& Weinberger, H. J. (1951). The L forms of bacteria. Bacteriological Reviews 15, 245-288.

Georgopapadakou, N. H. (1988). Penicillin-binding proteins. In Antimicrobial Agents Annual 4, pp. 409-431. Edited by P. K. Peterson \& J. Verhoef. Amsterdam: Elsevier Science Publishers.

GMEINER, J. (1975). The isolation of two different lipopolysaccharide fractions from various Proteus mirabilis strains. European Journal of Biochemistry 58, 621-626.

GMEINER, J. (1981). Characterization of a new murein-associated lipoprotein in the outer membrane of Proteus mirabilis. Archives of Microbiology 128, 299-302.

Gmeiner, J. \& Martin, H. H. (1976). Phospholipid and lipopolysaccharide in Proteus mirabilis and its stable protoplast L-form. Difference in content and fatty acid composition. European Journal of Biochemistry 67, 487-494.

Goldman, R. C., Joiner, K. A. \& Leive, L. (1984). Serum-resistant mutants of Escherichia coli O111 contain increased lipopolysaccharide, lack an $\mathrm{O}$-antigen containing capsule, and cover more of their lipid A with O-antigen. Journal of Bacteriology 159, 877-882.

GUMPERT, J., SChUHMANN, E. \& TAUBENECK, U. (1971). L-Formen von Escherichia coli K12. II. Elektronenoptische Untersuchungen. Zeitschrift für Allgemeine Mikrobiologie 11, 283-300.
Hasin, M., Rotrem, S. \& Razin, S. (1974). The outer membrane of Proteus mirabilis. I. Isolation and characterization of the outer and cytoplasmic membrane fractions. Biochimica et Biophysica Acta 375, 381-394.

HoFSChNEIDER, P. H. \& MARTIN, H. H. (1968). Diversity of surface layers in L-forms of Proteus mirabilis. Journal of General Microbiology 51, 23-33.

Huber, K. (1985). Quantitative Bewertung der Funktion von Penicillinbindeproteinen an der Sphäroplasten-L-Form von Proteus mirabilis nach Einwirkung verschiedener Klassen von $\beta$-Laktam-Antibiotika. Dissertation, Technische Hochschule Darmstadt.

JAMES, R. (1975). Identification of an outer membrane protein of Escherichia coli, with a role in the coordination of DNA replication and cell elongation. Journal of Bacteriology 124, 918-929.

Joiner, K. A., Schmetz, M. A., Goldman, R. C., Leive, L. \& Frank, M. M. (1984). Mechanism of bacterial resistance to complementmediated killing: inserted C5b-9 correlates with killing of Escherichia coli O111 : B4 varying in O-antigen capsule and O-polysaccharide coverage of lipid A core oligosaccharide. Infection and Immunity 45, 113-117.

Kroll, H.-P., Gmeiner, J. \& Martin, H. H. (1980). Membranes of the protoplast L-form of Proteus mirabilis. Archives of Microbiology 127, 223-229.

Lugtenberg, B., Meijers, J., Peters, R., van der Hoeck, R. \& Van ALPHEN, L. (1975). Electrophoretic resolution of the major outer membrane protein of Escherichia coli $\mathrm{K} 12$ into four bands. FEBS Letters 58, 254-258.

Markwell, M. A. K., HaAs, S. M., Bieber, L. L. \& Tolbert, N. E. (1978). A modification of the Lowry procedure to simplify protein determinations in membrane and lipoprotein samples. Analytical Biochemistry 87, 206-210.

Martin, H. H. (1964). Composition of the mucopolymer in cell walls of the unstable and stable L-form of Proteus mirabilis. Journal of General Microbiology 36, 441-450.

Martin, H. H. (1983). Protoplasts and spheroplasts of Gram-negative bacteria (with special emphasis on Proteus mirabilis). In Protoplasts 1983 (Lecture Proceedings), Experientia Supplementum, vol. 46, pp. 213-225. Edited by I. Potrykus, C. T. Harms, A. Hinnen, R. Hütter, P. J. King \& R. D. Shillito. Basel: Birkhäuser Verlag.

MARTIN, H. H. \& GMeINER, J. (1979). Modification of peptidoglycan structure by penicillin action in cell walls of Proteus mirabilis. European Journal of Biochemistry 95, 487-495.

MusChel, L. H. \& TREFFERS, H. P. (1955). Quantitative studies on the bactericidal actions of serum and complement. I. A rapid photometric growth assay for the bactericidal activity. Journal of Immunology 76, 1-10.

NakamuRa, K. \& Mizushima, S. (1975). In vitro reassembly of the membranous vesicle from Escherichia coli outer membrane components. Role of individual components and magnesium ions in reassembly. Biochimica et Biophysica Acta 413, 371-393.

Nixdorff, K., Fitzer, H., Gmeiner, J. \& Martin, H. H. (1977). Reconstitution of model membranes from phospholipid and outer membrane proteins of Proteus mirabilis. Role of proteins in the formation of hydrophilic pores and protection of membranes against detergents. European Journal of Biochemistry 81, 63-69.

NixdorfF, K., Martin, H. H. \& Siegmund-Schultze, N. (1985). Changes in outer membrane composition after treatment of Proteus mirabilis with antibiotics. In The Influence of Antibiotics on the HostParasite Relationship II, pp. 57-64. Edited by D. Adam, H. Hahn \& W. Opferkuch. Berlin, Heidelberg, New York \& Tokyo: SpringerVerlag.

Ohya, S., Yamazaki, M., Sugawara, S. \& Matsuhashi, M. (1979). Penicillin-binding proteins in Proteus species. Journal of Bacteriology 137, 474-479.

Osborn, M. J., Gander, J. E., Parisi, E. \& Carson, J. (1972). Mechanism of assembly of the outer membrane of Salmonella typhimurium. Journal of Biological Chemistry 47, 3962-3972.

Reynolds, B. L. \& PruUl, H. (1971). Protective role of smooth lipopolysaccharide in the serum bactericidal reaction. Infection and Immunity 4, 764-771.

Rogers, H. J. \& Thurman, P. F. (1983). Interrelationship between wall and membrane biosynthesis. In The Target of Penicillin, pp. 
637-641. Edited by R. Hackenbeck, J. V. Höltje \& H. Labischinsky. Hawthorne, New York: Walter de Gruyter.

Schnaltman, C. A. (1970). Protein composition of the cell wall and cytoplasmic membrane of Escherichia coli. Journal of Bacteriology 104, 890-901.

Siegmund-Schultze, N., Martin, H. H. \& Nixdorff, K. (1985). Effects of antibiotics on the sensitivity of Proteus mirabilis to the bactericidal action of normal human serum. In The Influence of Antibiotics on the Host-Parasite Relationship II, pp. 107-116. Edited by D. Adam, H. Hahn \& W. Opferkuch. Berlin, Heidelberg, New York \& Tokyo: Springer-Verlag.

SPRATT, B. G. (1975). Distinct penicillin-binding proteins involved in the division, elongation and shape of Escherichia coli K12. Proceedings of the National Academy of Sciences of the United States of America 72, 2999-3003.

SPRATT, B. G. (1977). Properties of the penicillin-binding proteins of Escherichia coli K12. European Journal of Biochemistry 72, 342-352.

Suerbaum, S., Leying, H., Kroll, H.-P., Gmeiner, J. \& OpferkuCh, W. (1987). Influence of $\beta$-lactam antibiotics and ciprofloxacin on cell envelope of Escherichia coli. Antimicrobial Agents and Chemotherapy 31, 1106-1110.
TAYLOR, P. W. (1983). Bactericidal and bacteriolytic activity of serum against Gram-negative bacteria. Microbiological Reviews 47, 46-83.

TAYLOR, P. W. \& KROLL, H.-P. (1984). Interaction of human complement proteins with serum-sensitive and serum-resistant strains of Escherichia coli. Molecular Immunology 21, 609-620.

Taylor, P. W., Gaunt, H. \& UNGER, F. M. (1981). Effect of subinhibitory concentrations of mecillinam on the serum susceptibility of Escherichia coli strains. Antimicrobial Agents and Chemotherapy 19, 786-788.

TAYloR, P. W., KRoll, H.-P. \& Tomlinson, S. (1982). Effect of subinhibitory concentrations of mecillinam on expression of Escherichia coli surface components associated with serum resistance. Drugs under Experimental and Clinical Research 6, 625-631.

VAN HeErikhuisen, H., KWak, E., van Bruggen, E. \& Witholt, B. (1975). Characterization of a low density cytoplasmic subfraction isolated from Escherichia coli. Biochimica et Biophysica Acta 413 , 177-191.

WestPhal, O., LüDERITZ, O. \& BISTER, F. (1952). Über die Extraktion von Bakterien mit Phenol/Wasser. Zeitschrift für Naturforschung (Teil B) 7, 108-155. 